\title{
ANALISIS HUBUNGAN ANTARA BERBAGAI DIMENSI SIKAP INDIVIDUAL DALAM MENGELOLA KELUARGA DAN KARIER
}

\author{
Nuryati
}

\begin{abstract}
This research aims to analyze relationship between individual attitude to the managing family and career. This study is based on Sander M. M., Lengnick-Hall, C. A., Lengnick-Hall, M. L., \& Steele-Clapp, L. (1998) study.

Data for this study were provided by 217 students of the last level of Universities taken from state and private Universities at Yogyakarta. Individual attitude is measured by using CFAM from Sander et al. (1998). Response rate of this study was 95,2\%. The data were analized by correlation analysis.

This study found eight important results. First, spousal supports and dominances, is positively corrrelated with other scales. Second, for the males and females, is positively correlated significantly between spousal suppports and balances. Third, for the males, is positively correlated significantly between family focus and career focus, whereas it was not for the females. Fourth, for the males, is positively correlated significantly between career focus and balances, whereas it was not for the females. Fifth, for the males, is positively correlated significantly between independences and family focus, whereas it was not for the females. Sixth, for the males and females, is significantly uncorrelated between independences and career focus. Seventh, for the males and females, is significantly uncorrelated between independences and dominances. Eighth, for the males and females, is significantly uncorrelated between independences and spousal supports.
\end{abstract}

Keywords: individual attitude, CFAM(career-family attitudes measures), correlation analysis.

\section{PENDAHULUAN}

Akhir-akhir ini angkatan kerja yang memasuki dunia kerja makin meningkat, sehingga persaingan untuk mendapatkan pekerjaan semakin ketat. Persaingan ini bukan hanya datang dari angkatan kerja pria tetapi juga dari angkatan kerja wanita, hal ini karena diskriminasi terhadap gender sudah tidak begitu menyolok. Saat ini telah terjadi perubahan kecenderungan demografi yang melanda seluruh dunia, dimana ada peningkatan jumlah wanita yang termasuk dalam angkatan kerja dan semakin lazimnya suatu keluarga dengan suami istri bekerja (Frone et al., 1992), lebih lanjut Vinokur et al. (1999) menyatakan bahwa partisipasi wanita dalam angkatan kerja mendekati 50 persen.

Partisipasi wanita dalam angkatan kerja berpengaruh baik secara langsung maupun tidak langsung terhadap keluarganya. Wanita bekerja yang lebih mencurahkan pada keluarga, pada umumnya kepuasan kariernya lebih rendah dibandingkan dengan wanita yang hanya menfokuskan pada pekerjaannya. Begitu juga dengan pria yang lebih berkonsentrasi pada pekerjaan maka perhatiannya terhadap keluarga menjadi kurang sehingga kepuasan keluarganya rendah. Demikian pula dengan keluarga yang suami istri bekerja, perhatiannya terhadap keluarga menjadi kurang, sehingga kepuasan keluarga juga rendah. Pekerjaan yang mengganggu kehidupan keluarga kemungkinan menyebabkan ketidakpuasan anggota keluarga lainnya akibatnya muncul masalah yang serius seperti perpisahan, perceraian (Yang et al. ,2000). Anak sebagai anggota keluarga menjadi korban karena kesibukan dan ambisi orang tua. Akibatnya anak berperilaku yang tidak benar, misalnya lari pada obat-obatan terlarang dan terjerumus pada pergaulan bebas. 
Anak sebagai penerus garis keturunan keluarga seharusnya mendapatkan kasih sayang, perhatian, dan pendidikan dari orang tua agar perilakunya tidak menyimpang. Hal ini karena perilaku anak banyak dipengaruhi oleh keluarga. Di samping itu, anak juga akan bersikap yang pada umumnya lebih banyak terbentuk dari keluarga. Sander et al. (1998) menyatakan bahwa peran ibu sebagai wanita karier atau ibu rumah tangga sangat kuat mempengaruhi sikap anak terhadap keluarga dan karier. Ada yang meniru atau mengimpikan menjadi seperti orang tuanya dan sebaliknya ada yang menentang atau menolak untuk menjadi seperti orang tuanya. Jika anak terdidik dengan baik maka generasi bangsa akan berkualitas dan mampu bersaing di dunia kerja. Penelitian ini menganalisis hubungan antara berbagai dimensi sikap individual baik pria maupun wanita dalam mengelola keluarga dan karier dari kelompok anak muda yang akan memasuki dunia kerja. Maksud dari pengelolaan karier dan keluarga adalah bahwa individu yang telah berumah tangga berusaha menyeimbangkan antara karier dan keluarga. Dengan kata lain, pengelolaan keluarga dan karier adalah bagaimana individu melakukan/mengatur pekerjaannya tanpa mengabaikan pekerjaan rumah tangganya.

Hasil penelitian yang dilakukan oleh Sander et al. (1998) di Minnesota dan Winconsin, USA, menunjukkan bahwa sikap pelajar SMU dan SMP terhadap karier dan keluarga berhubungan positif, seperti sikap individu lebih positif terhadap karier sedang sikap individu yang lain lebih negatif terhadap keluarga, dengan kata lain individu lebih memilih satu hal yaitu karier atau keluarga. Hasil penelitian tersebut mengindikasikan bahwa sikap individu dalam mengelola keluarga dan karier berkaitan dengan preference atau pilihan untuk mengintegrasikan karier dan keluarga dan bukan menyeimbangkan antara karier dan keluarga.

Untuk membuktikan adanya hubungan yang signifikan antara berbagai dimensi sikap individual baik pria maupun wanita dalam mengelola keluarga dan karier, penelitian ini menguji kembali pengukuran sikap keluarga berkarier (Career-Family Attitudes Measure (CFAM)) yang sebelumnya telah digunakan oleh Sander et al. (1998) di lingkungan sekolah menengah umum dan sekolah menengah pertama di Minnesota dan Winconsin, USA, dengan sampel pelajar baik pria maupun wanita. Instrumen CFAM tersebut menggunakan enam dimensi karier dan keluarga yaitu family focus (orientasi pada keluarga), balance (keseimbangan), career focus (orientasi pada karier), dominance (berkuasa), spousal support (dukungan suami/istri), dan independence (kebebasan).

Penelitian ini berbeda dengan penelitian sebelumnya yang telah dilakukan oleh Sander et al.. (1998). Dalam penelitian ini, sampel yang dipilih adalah sampel dari lingkungan Perguruan tinggi baik negeri maupun swasta yang berada di wilayah DIY sedangkan penelitian sebelumnya menggunakan sampel pelajar SMU dan SMP di Minnesota dan Winconsin, USA. Peneliti memilih mahasiswa tingkat akhir baik pria maupun wanita. Peneliti memilih mahasiswa tingkat akhir karena mereka potensial memasuki dunia kerja setelah jadi sarjana dan juga potensial untuk memasuki mahligai rumah tangga. Secara umum, tujuan penelitian ini menganalisis hubungan antara berbagai dimensi sikap individual baik pria maupun wanita dalam mengelola keluarga dan karier dari kelompok anak muda.

\section{LANDASAN TEORI DAN HIPOTESIS}

Pada saat ini studi tentang pengelolaan keluarga dan pekerjaan memperlihatkan peningkatan, tetapi instrumen yang tersedia masih sedikit, misalnya definisi secara komprehensif, pengukuran, dan model yang mempengaruhi kehidupan dalam pekerjaan dan kehidupan keluarga (Sander et al., 1998). Walaupun penelitian yang telah dilakukan mempunyai hubungan positif antara kepuasan kehidupan dalam pekerjaan dan kepuasan kehidupan keluarga, tetapi ada beberapa fakta yang menunjukkan bahwa hubungan tersebut tidak kausal atau timbal balik (Frone et al., 1994). Dengan kata lain, walaupun mereka berbeda, ketidakpuasan kehidupan dalam pekerjaan tidak dapat secara langsung menyebabkan ketidakpuasan kehidupan keluarga. Sebaliknya ketidakpuasan 
kehidupan keluarga tidak mempunyai hubungan kausal secara langsung dengan ketidakpuasan kehidupan dalam pekerjaan.

\section{1. Sikap Keluarga Berkarier}

Sikap individual dalam mengelola keluarga dan karier ini didefinisikan sebagai pola preferensi yang mempunyai keseimbangan (trade-off) diantara spectrum keluarga dan pekerjaan (Sander et al., 1998). Definisi ini terdiri dari beberapa tema (Sander et al., 1998). Kata pola (pattern) dan spectrum mengindikasikan bahwa keluarga dan pekerjaan adalah multidimensional, mempunyai relevansi terhadap karier atau keluarga, patner, anak, pendidikan, dan waktu luang. Kata preferensi digunakan untuk mencakup komponen sikap keluarga berkarier yang disengaja (intentional) dan menarik (Sander et al., 1998; dikutip dari Triandis, 1971). Akhirnya, kata keseimbangan (trade-off) digunakan oleh keluarga berkarier yang pengambilan keputusannya dilakukan secara bersamasama, berbagi tanggung jawab rumah tangga, dan penekanan pada kedua karier.

Sikap individu dalam mengelola keluarga dan karier menggunakan enam dimensi. Family Focus (orientasi pada keluarga) menyinggung tentang salah satu pasangan hidup (suami/istri) yang mau mengalah karier pasangan hidupnya (suami/istri) agar menfokuskan pada keluarga dengan tinggal di rumah untuk melakukan pekerjaan rumah tangga dan mengasuh/merawat anak (Sander et al., 1998). Karena beberapa item dalam skala ini menunjukkan adanya kepatuhan pada karier oleh responden dan beberapa item menunjukkan bahwa salah satu pasangan hidup (suami/istri) mau mengalah atau patuh tanpa syarat terhadap pasangan hidupnya (suami/istri), maka variabel ini dibagi menjadi dua yaitu: saya tunduk (I defer) dan seseorang tunduk (someone defers). Balance (keseimbangan) menyinggung tentang pembagian tugas dan keputusan yang berkaitan dengan kehidupan rumah tangga dan penekanan yang sama baik pada karier maupun pendidikan pasangan hidupnya (Sander et al., 1998). Career Focus (orientasi pada karier) menyinggung tentang perhatian yang lebih terhadap pekerjaan, kesempatan dalam pekerjaan daripada hubungan ibu atau anak (Sander et al.,1998). Dominance (berkuasa) menyinggung tentang kepemilikan karier dan decision power salah satu pasangan hidup (suami/istri) dalam kehidupan rumah tangga mereka sedangkan pasangan hidupnya (suamilistri) berkarier untuk mengurus anak (Sander et al., 1998). Spousal Support (dukungan suami/istri) menyinggung bahwa salah satu pasangan hidup (suami/istri) akan supportive dengan memberi dukungan meskipun dalam kondisi tidak setuju, misalnya responden pindah karena menerima tawaran kerja yang bagus di tempat lain, melakukan pekerjaan rumah bila tidak ada yang mengerjakan, dan meminimumkan gangguan weekend (Sander et al., 1998). Independence (kebebasan) menyinggung tentang sosialisasi dan kebebasan liburan dari salah satu pasangan (Sander et al., 1998).

\section{2. Keseimbangan Kehidupan dalam Keluarga dan Pekerjaan}

Kehidupan dalam keluarga dan kehidupan pekerjaan merupakan dua domain kehidupan orang dewasa yang paling sentral dan juga merupakan dua domain kehidupan yang saling berkaitan dan sulit dipisahkan (Frone et al. , 1992). Menurut Mercer (1991) dikutip oleh Yasin (1999) memberi bukti bahwa para pekerja cenderung lebih produktif jika mereka dapat mengembangkan peran kerja dan keluarga, lebih lanjut Frone et al. (1992) mengemukakan bahwa pekerjaan mengganggu keluarga dan keluarga mengganggu pekerjaan.

Studi tentang keterkaitan antara kehidupan dalam pekerjaan dan kehidupan keluarga sudah banyak dilakukan oleh peneliti terdahulu ( Frone et al.,1992; Frone dan Cooper, 1994). Kehidupan dalam keluarga dan kehidupan pekerjaan penting bagi peneliti organisasional dan manajer karena potensial mempengaruhi kepuasan kerja, keterlibatan kerja, dan komitmen organisasional (Sander et al., 1998). Sebagai contoh, Burke dan Mckeen (1993) menemukan bahwa wanita yang mencoba untuk menyeimbangkan antara pekerjaan dan keluarga menunjukkan bahwa kepuasan kerjanya lebih rendah dibandingkan dengan wanita yang hanya menekankan pada satu hal yakni karier. Dengan 
mengkonsentrasikan pada satu hal yakni karier atau keluarga maka hasilnya lebih maksimal dibandingkan yang menyeimbangkan keluarga dan karier hasilnya tidak maksimal. Menurut Wallace (1999) wanita yang telah menikah dan sudah profesional dalam bekerja secara simultan cenderung memprioritaskan baik pekerjaan maupun keluarga, sedangkan pria yang telah menikah dan sudah profesional dalam bekerja cenderung memilih untuk menfokuskan pada pekerjaan dan kurang bertanggungjawab terhadap keluarganya. Sejumlah penelitian melaporkan bahwa wanita profesional yang telah menikah memikul beban rumah tangga yang berat dibandingkan dengan suaminya. Martin, Harrison, dan Dinitto (1983) berasumsi bahwa tanggung jawab utama wanita adalah rumah dan merawat anak sampai dewasa sehingga mempunyai pengaruh negatif terhadap kemajuan kariernya. Lebih lanjut Vinokur, Pierce, dan Buck (1999) berpendapat bahwa wanita profesional yang memiliki status karier yang relatif sama dengan suami, pola dalam mendistribusikan tugas dan tanggung jawab terhadap anak di rumah tidak menguntungkan bagi wanita, hal ini karena wanita lebih kritis terhadap pekerjaan rumah daripada pria.

Untuk dapat mencapai keseimbangan antara kehidupan keluarga dan kehidupan pekerjaan maka Mercer (1991) yang dikutip oleh Yasin (1999) membuat pilihan program. Waktu on the job dan off the job, program ini menawarkan bahwa kontrol atas waktu kerja ada pada para pekerja. Sebagai contoh, program flextime atau job-sharing. Program flextime, berarti para pekerja dapat memilih bekerja lebih awal atau terlambat. Job-sharing menawarkan bahwa satu pekerjaan dibagi dua orang atau lebih, atau pengaturan waktu kerja, seperti kerja penuh pada hari minggu atau hanya kerja setengah hari. Bantuan perawatan untuk keluarga pekerja, bantuan ini berupa jasa yang diberikan oleh perusahaan kepada anggota keluarga pekerja (seperti anak atau orang tua) yang menjadi tangung jawabnya. Jenis jasa perawatan spesifik: untuk bayi, anak yang sakit, penitipan orang tua. Asuransi kesehatan, jasa ini memberikan jaminan kesehatan dengan model dua jenjang atau lebih. Maksudnya, jaminan kesehatan ini tidak hanya dirinya, anak dan istrinya melainkan semua keluarga yang menjadi tanggungannya.

2. 3. Hubungan antara Berbagai Dimensi Sikap Individual (family focus, balance, career focus, balance, dominance, dan independence) baik Pria maupun Wanita dalam Mengelola Keluarga dan Karier.

Penelitian ini mendasarkan pada adanya hubungan antara berbagai dimensi sikap individual baik pria maupun wanita dalam mengelola keluarga dan mengelola karier. Hasil penelitian Sander et al.. (1998) menemukan bahwa sikap individu terhadap pengelolaan keluarga dan karier berhubungan positif, seperti sikap individu lebih positif terhadap karier sedang sikap individu lain lebih negatif terhadap keluarga, dengan kata lain individu lebih memilih satu hal yaitu karier atau keluarga. Sikap individu baik pria maupun wanita mempunyai enam dimensi yaitu family focus, balance, career focus, dominance, spousal support, dan independence. Penemuan tersebut secara rinci menjelaskan adanya perbedaan korelasi antara sikap individu dalam mengelola keluarga dan karier pada pria dan wanita. Pada wanita, ada hubungan negatif signifikan antara family focus dan career focus dan sebaliknya tidak pada pria. Pada wanita, ada hubungan positif signifikan antara career focus dan balance dan sebaliknya tidak pada pria. Pada wanita, ada hubungan negatif antara family focus dan independence dan sebaliknya pada pria. Pada pria, independence berhubungan positif dengan career focus dan dominance. Pada pria, ada hubungan positif signifikan antara independence dan spousal support dan sebaliknya tidak pada wanita. Pada pria, ada hubungan negatif antara balance dan spousal support dan sebaliknya pada wanita.

Sikap individu pada umumnya berhubungan dengan pengalaman (realita yang dialami). Teori Person- environment fit ( PE fit) yang dikemukan oleh Edwards dan Harrison (1993) mendalilkan bahwa besarnya gap antara kebutuhan dan preferensi individu dan kemampuan lingkungan untuk memuaskan kebutuhan dan preferensi yang merupakan sebuah pengukuran PE fit dan misfit menimbulkan stress dan ketegangan psikologic, pisiologic, dan fungsi perilaku. Berdasarkan teori PE 
fit dan teori fit lainnya antara realitas dan harapan, apabila terjadi gab antara realitas dan sikap individual maka akan menimbulkan ketidakpuasan, stress, ketegangan, konflik, dan hasil yang tidak diinginkan.

Sander et al. (1998) menggambarkan hal ini dengan mewawancarai beberapa karyawan pria di New York Times dan CBS, dimana dalam wawancara tersebut diindikasi bahwa mereka meyakini perkawinan tradisional. Mereka mendefinisikan perkawinan tradisional sebagai perkawinan yang mana istri tinggal di rumah, merawat anak, memasak, dan mencuci, sedangkan suami bertanggungjawab untuk mencari uang dan memotong rumput di halaman (Lewin, 1994). Singh (1994) berasumsi bahwa pria bekerja untuk memperoleh penghasilan utama dalam keluarga sedangkan wanita bekerja hanya untuk menambah penghasilan keluarga. Kebanyakan wanita yang diwawancarai tidak merubah rencana mereka untuk berkarier dan mempunyai perkawinan yang sederajat dengan lainnya (Sander et al., 1998). Gap antara sikap kaum muda dan realitas akan luas ketika mereka menikah dan menemukan harapan. Gap juga akan meluas dalam peristiwa dimana mereka menemukan patner yang bisa sharing sikap, tetapi kemudian menemukan kelangsungan ekonomi mereka atau kesejahteraan anak mereka terancam oleh realitas yang tidak sesuai dengan sikap mereka. Berdasarkan uraian di atas, maka hipotesis yang diajukan adalah:

Hipotesis : Ada hubungan antara berbagai dimensi sikap individual (family focus, balance, career focus, balance, dominance, dan independence) baik pria maupun wanita dalam mengelola keluarga dan karier.

H1a: Ada hubungan yang signifikan antara spousal support dan balance pada pria dan wanita. H1b: Ada hubungan yang signifikan antara family focus dan career focus pada pria dan wanita. H1c: Ada hubungan yang signifikan antara career focus dan balance pada pria dan wanita.

H1d: Ada hubungan yang signifikan antara independence dan family focus pada pria dan wanita. H1e: Ada hubungan yang signifikan antara independence dan career focus pada pria dan wanita. H1f: Ada hubungan yang signifikan antara independence dan dominance pada pria dan wanita H1g: Ada hubungan yang signifikan antara independence dan spousal support pada pria dan wanita.

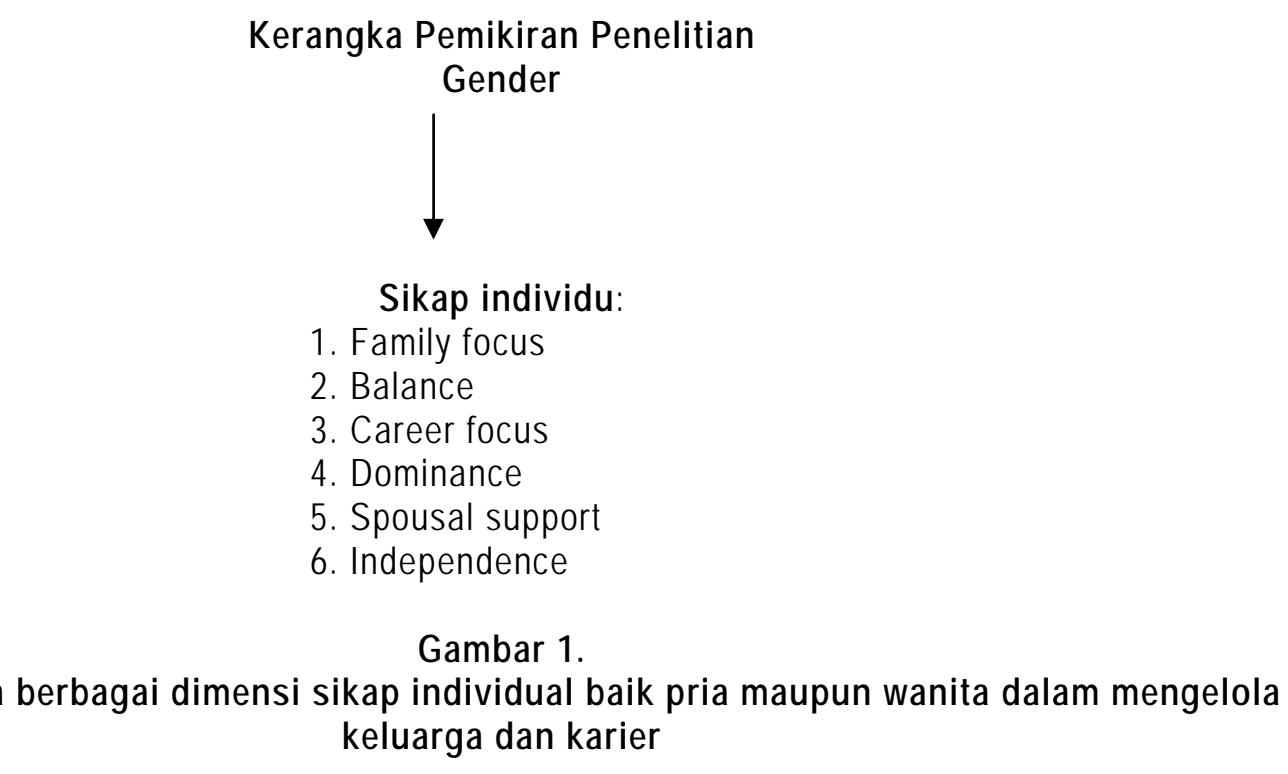

\section{METODOLOGI PENELITIAN}

\section{1. Sampel Penelitian}

Penelitian ini dilakukan di lingkungan Perguruan tinggi yang berada di wilayah DIY. Untuk mendukung penelitian ini, maka peneliti menyebarkan kuesioner sejumlah 230 . Tehnik pengambilan 
sampel dalam penelitian ini adalah purposive sampling, artinya sampel nonprobability yang menyesuaikan diri dengan kriteria tertentu (Cooper dan Emory, 1995). Kriteria responden yang dijadikan sampel dalam penelitian ini adalah mahasiswa tingkat akhir baik pria maupun wanita.

\section{2. Metode Pengumpulan Data}

Data yang dipergunakan dalam penelitian ini adalah data primer dan dikumpulkan dengan cara menyebarkan kuesioner kepada mahasiswa tingkat akhir di beberapa Perguruan tinggi yang sudah ditentukan yakni UGM dan UAJY. Kuesioner dirancang dalam format pertanyaan yang tidak terlalu panjang dan jelas sehingga lama pengisian tidak lebih dari 30 menit. Setiap responden diminta untuk mengisi kuesioner yang terdiri dari 56 item. Setiap item dari pertanyaan kuesioner yang diberikan kepada responden menggunakan Skala Likert yang berbobot 7 point untuk mengukur setiap variabel penelitian dengan jawaban dari Sangat Tidak Setuju (1) sampai Sangat Setuju (7). Response rate sebesar 95,22\% (219 kuesioner) dan kuesioner lengkap yang diolah dalam penelitian ini sebesar 217 kuesioner.

\section{3. Definisi Operasional dan Pengukuran Instrumen Penelitian}

Pengukuran sikap individu terhadap pengelolaan keluarga dan karier ini menggunakan 56 item instrumen Career-Family Attitudes Measure (CFAM) yang dikembangkan oleh Hai (1986) dan telah digunakan oleh Sander et al. (1998), dengan menggunakan 7 skala Likert, dimana 1 sampai 3 ( sangat tidak setuju) dan 5 sampai 7 (sangat setuju).

\section{Family Focus (orientasi pada keluarga)}

Family focus menyinggung tentang salah satu pasangan hidup (suami/istri) mau mengalah terhadap karier pasangan hidupnya (suami/istri) agar menfokuskan pada keluarga dengan tinggal di rumah untuk melakukan pekerjaan rumah dan mengasuh atau merawat anak. Karena beberapa item dalam skala ini menunjukkan adanya kepatuhan pada karier oleh responden dan beberapa item menunjukkan bahwa salah satu pasangan hidup (suami/istri) mau mengalah atau patuh tanpa syarat terhadap pasangan hidupnya (suami/istri), maka variabel ini dibagi menjadi dua yaitu: saya tunduk (I defer) dan seseorang tunduk (someone defers). Subvariabel I defer diukur dengan 10 butir pertanyaan (item $2,8,15,23,26,27,31,33,41$, dan 42) sedang subvariabel someone defers diukur dengan 6 butir pertanyaan ( item 1,3,22, 25, 48, dan 20). Pada penelitian ini family focus telah diukur reliabilitasnya ( $\alpha=0.61$ ), dimana reliabilitas untuk I defer besarnya adalah $\alpha=0.60$ sedang reliabilitas untuk Someone Defers besarnya adalah $\alpha=0.77$.

\section{Balance (keseimbangan)}

Balance menyinggung tentang pembagian tugas dan keputusan yang berkaitan dengan rumah dan penekanan yang sama baik pada karier maupun pendidikan pasangan hidupnya (suami/istri). Variabel ini diukur dengan 10 butir pertanyaan (item 9, 14, 16, 37, 39, 43, 44, 46, 47, dan 55) yang berkaitan dengan keseimbangan antara karier dan pendidikan. Pada penelitian ini reliabilitasnya adalah $\alpha=0.56$.

\section{Career Focus (orientasi pada karier)}

Career focus menyinggung tentang perhatian yang lebih terhadap pekerjaan, kesempatan dalam pekerjaan daripada hubungan ibu atau anak. Variabel ini diukur dengan 6 butir pertanyaan (item 19, 24, 34, 38, 49, dan 53). Reliabilitas pada penelitian ini adalah $\alpha=0.59$.

\section{Dominance (berkuasa)}

Dominance menyinggung tentang kepemilikan karier dan decision power dalam rumah sedangkan pasangan hidupnya (suami/istri) berkarier untuk mengurus anak. Variabel ini diukur dengan 8 butir pertanyaan (item 7, 13, 17, 28, 29, 32, 40, dan 54). Pada penelitian ini reliabilitasnya adalah $\alpha=0.58$. 


\section{Spousal Support (dukungan suamilistri)}

Spousal support menyinggung bahwa salah satu pasangan hidup (suami/istri) akan supportive dengan memberi dukungan meskipun dalam kondisi tidak setuju, misalnya responden pindah karena menerima tawaran kerja yang bagus di tempat lain, melakukan pekerjaan rumah bila tidak ada yang mengerjakan, dan meminimumkan gangguan weekend. Variabel ini diukur dengan 8 butir pertanyaan (item $4,6,18,35,36,45,51$, dan 56). Pada penelitian ini reliabilitasnya adalah $\alpha=0.63$.

\section{Independence (kebebasan)}

Independence menyinggung tentang sosialisasi dan kebebasan liburan dari salah satu pasangan (suami/istri). Variabel ini diukur dengan 4 butir pertanyaan (item 5, 21, 30, dan 52). Pada penelitian ini reliabilitasnya adalah $\alpha=0.63$.

\subsection{Uji Validitas}

Untuk melakukan uji validitas digunakan faktor analisis. Karena item-item pertanyaan dalam kuesioner diadopsi dari penelitian sebelumnya maka faktor analisis yang dilakukan bersifat confirmatory. Untuk menyesuaikan dengan enam faktor tersebut dilakukan varimax rotation untuk membantu membuat unrotated factor loadings yang besar menjadi lebih besar dan sebaliknya yang kecil menjadi lebih kecil, sehingga hasilnya akan lebih mudah untuk diintepretasikan. 
Tabel 1. Hasil Analisis Faktor Setelah Rotasi

\begin{tabular}{|c|c|c|c|c|c|c|}
\hline & \multicolumn{6}{|c|}{ Component } \\
\hline & 1 & 2 & 3 & 4 & 5 & 6 \\
\hline ITEM_7 & ,623 & & & & & \\
\hline ITEM_4 & ,557 & & & & & \\
\hline ITEM_28 & ,514 & & -397 & & & \\
\hline ITEM_6 & 498 & & & & & \\
\hline ITEM_27 & 497 & & & & & \\
\hline ITEM_22 & 447 & & & & &,- 271 \\
\hline ITEM_13 & 401 & & 280 & & & 279 \\
\hline ITEM_26 & ,361 & & ,220 & & &, 3601 \\
\hline ITEM_48 & ,352 & -219 & & &,- 305 & \\
\hline ITEM_32 & ,327 & &,- 246 & &,- 226 & \\
\hline ITEM_18 & 262 & 262 & & & & \\
\hline ITEM_53 & 246 & ,232 & & & & \\
\hline ITEM_47 & & ,710 & & & & \\
\hline ITEM_29 & & ,707 & & & & \\
\hline ITEM_51 & & 651 & & & 263 & \\
\hline ITEM_37 & & ,535 & 210 & & 261 & \\
\hline ITEM_43 & & ,512 & & & & \\
\hline ITEM_17 & & ,479 & & & & ,206i \\
\hline ITEM_15 & &,- 321 & ,231 & & & \\
\hline ITEM_56 & & 237 & & & & \\
\hline ITEM_23 & - 247 & & 680 & & & \\
\hline ITEM_42 & & & 643 & & & \\
\hline ITEM_35 & & & ,546 & & & \\
\hline ITEM_33 & & & 498 & 204 & &,$- 29 c 1$ \\
\hline ITEM_41 & 266 & & 463 & & & - $26 i^{\prime}$ \\
\hline ITEM_54 & ,354 & 287 & -,417 & & & \\
\hline ITEM_40 & & & &, 594 & & \\
\hline ITEM_8 & & & & ,586 & & \\
\hline ITEM_39 & & & ,310 & ,552 & & \\
\hline ITEM_46 & & & & ,550 & & \\
\hline ITEM_9 & & & ,326 & ,433 & & \\
\hline ITEM_20 & & & 276 & 421 & 217 & \\
\hline ITEM_25 & 293 &,- 315 & &,- 373 & & \\
\hline ITEM_50 & & 284 & & 341 & & \\
\hline ITEM_11 & & & &,- 332 & & \\
\hline ITEM_10 & & & & -319 & & \\
\hline ITEM_5 & & & &,- 251 & & \\
\hline ITEM_1 & & & & & & \\
\hline ITEM_45 & 398 & & & & 663 & \\
\hline ITEM_36 & 447 & & & & 658 & \\
\hline ITEM_44 & & & ,300 & & ,497 & \\
\hline ITEM_30 & & & & & - 446 & $32 i^{\prime}$ \\
\hline ITEM_31 & & & 221 & 224 & ,368 & \\
\hline ITEM_3 & & & & & ,349 & \\
\hline ITEM_12 & & & 298 & 319 & 332 & \\
\hline ITEM_16 & & ,223 & & & 331 & \\
\hline ITEM_2 & & & & & ,319 & \\
\hline ITEM_14 & & & & & 295 & \\
\hline ITEM_19 & & & & & 252 & \\
\hline ITEM_21 & & & & & & (61 \\
\hline ITEM_38 & & & & & &, $54 \hat{\prime}$ \\
\hline ITEM_24 & & & & 207 & &, 520 \\
\hline ITEM_52 & & & & & & ,46z: \\
\hline ITEM_55 & ,229 & & & & & , \\
\hline ITEM_49 & & 228 & & & & $42 i^{\prime}$ \\
\hline ITEM_34 & ,304 & ,253 & & & & $-32 \varepsilon$ \\
\hline
\end{tabular}

Extraction Method: Principal Component Analysis.

Rotation Method: Varimax with Kaiser Normalization.

a. Rotation converged in 14 iterations. 


\subsection{Uji Reliabilitas}

Reliabilitas dapat diukur dengan menggunakan koefisien cronbach alpha dari hasil analsis faktor. Instrumen penelitian disebut handal bila pengujian tersebut menunjukkan alpha lebih dari 0,7 (Sekaran, 1992). Nilai alpha antara 0,80 sampai dengan 1,0 dikategorikan reliabilitas baik, nilai alpha antara 0,60 sampai dengan 0,79 dikategorikan reliabilitas diterima, dan nilai alpha kurang dari 0,60 dikategorikan reliabilitas kurang baik (Sekaran, 1992). Sedangkan Trisnoningtias dan Malo yang dikutip oleh Yasin (1999) memberikan kriteria bahwa nilai alpha kurang dari 0,50 dikategorikan reliabilitas rendah, nilai alpha antara 0,50 sampai dengan 0,89 dikategorikan sedang, dan nilai alpha antara 0,90 sampai dengan 1,0 dikategorikan reliabilitas tinggi.

Tabel 2. Ringkasan Hasil Uji Reliabilitas

\begin{tabular}{clcl}
\hline No. & \multicolumn{1}{c}{ Variabel } & Cronbach Alpha & \multicolumn{1}{c}{ Kriteria } \\
\hline 1 & Family Focus & 0.61 & Reliabilitas sedang \\
$1 \mathrm{a}$ & I Defer & 0.60 & Reliabilitas sedang \\
1b & Someone Defers & 0.77 & Reliabilitas sedang \\
2 & Balance & 0.56 & Reliabilitas kurang baik \\
3 & Career Focus & 0.59 & Reliabilitas kurang baik \\
4 & Dominance & 0.58 & Reliabilitas kurang baik \\
5 & Spousal Support & 0.63 & Reliabilitas sedang \\
6 & Independence & 0.63 & Reliabilitas sedang \\
\hline
\end{tabular}

Berdasarkan kriteria yang diberikan oleh Trisnoningtias dan Malo, hasil uji reliabilitas untuk semua variabel yang digunakan dalam penelitian ini adalah masuk dalam kategori sedang. Sedangkan Sekaran (1992) memberi kriteria yang berbeda. Nilai alpha tiga variabel yaitu variabel Family Focus ( I defer dan Someone defers), variabel Spousal Support, dan variabel Independence, ketiganya masuk kategori sedang, dan variabel sisanya terdiri dari variabel Balance, variabel Career Focus, dan variabel Dominance, mempunyai nilai alpha masuk dalam kategori kurang baik. Pada penelitian Sander et al.. (1998) ketiga variabel tersebut mempunyai nilai koefisien alpha dalam kategori sedang.

\subsection{Tehnik Analisis Data}

Untuk menguji hipotesis penelitian ini maka digunakan analisis koefisien korelasi Pearson. Analisa korelasi ini digunakan untuk mengetahui keeratan hubungan antara berbagai dimensi sikap individual dalam mengelola keluarga dan karier.

\section{ANALISIS HASIL PENELITIAN}

\section{1. Hasil Analisis Korelasi}

Penelitian ini dianalisis dengan menggunakan analisis korelasi. Hasil analisis korelasi dan statistik deskriptif dapat dilihat pada Tabel 3. 
Tabel 3. Statistik Deskriptif dan Interkorelasi Skala

\begin{tabular}{|c|c|c|c|c|c|c|c|c|c|c|}
\hline No. & Skala & Mean & $\begin{array}{l}\text { Standar } \\
\text { Deviasi }\end{array}$ & 1 & $1 a$ & $1 b$ & 2 & 3 & 4 & 5 \\
\hline 1 & Fam Foc & 70,69 & 9,14 & & & & & & & \\
\hline $1 a$ & I def & 40,75 & 6,74 & $0,895^{* *}$ & & & & & & \\
\hline $1 b$ & One def & 29,94 & 4,33 & $0,719^{* *}$ & $0,33^{\star *}$ & & & & & \\
\hline 2 & Balance & 54,39 & 6,08 & $0,290^{* *}$ & $0,321^{* *}$ & 0,114 & & & & \\
\hline 3 & Car Foc & 24,39 & 5,11 & $0,143^{*}$ & $0,136^{*}$ & 0,090 & $0,191^{* *}$ & & & \\
\hline 4 & Domin & 35,59 & 5,81 & $0,210^{* *}$ & $0,136^{*}$ & $0,231^{*}$ & $0,267^{* *}$ & $\begin{array}{l}0,156 \\
*\end{array}$ & & \\
\hline 5 & Spo Sup & 36,46 & 5,81 & $0,324^{* *}$ & 0,214 ** & $0,351^{* *}$ & $0,353^{* *}$ & $\begin{array}{l}0,242 \\
\star *\end{array}$ & $\begin{array}{l}0,433 \\
* *\end{array}$ & \\
\hline 6 & Indep & 14,82 & 4,88 & 0,027 & $-0,012$ & 0,074 & 0,004 & 0,116 & 0,030 & 0,017 \\
\hline
\end{tabular}

1. Family Focus; 1a. I Defer; 1b. Someone Defers; 2. Balance; 3. Career focus; 4. Dominance; 5. Spousal Support; 6 . Independence.

* $p<=0.01$

** $p<=0.05$

Hasil statistik deskriptif menunjukkan bahwa independence dan Career Focus mempunyai skor rata-rata yang rendah. Ini menunjukkan bahwa sikap individu secara kolektif adalah negatif terhadap karier pasangan hidupnya yang lebih mempunyai perhatian terhadap pekerjaan atau kebebasan liburan dan sosialisasi. Balance dan Family Focus mempunyai skor rata-rata yang tinggi. Ini menunjukkan bahwa kebanyakan responden mempunyai sikap positif terhadap pembuatan keputusan bersama-sama dengan pasangan hidup mereka, berbagi tanggung jawab rumah tangga, dan penekanan pada keduanya (keluarga dan karier).

Hasil penelitian ini tidak konsisten dengan hasil penelitian Sander et al. (1998), dimana mereka menemukan skor rata-rata yang rendah pada skala family focus dan dominance dan skor rata-rata yang tinggi pada skala balance dan independence. Perbedaan ini disebabkan kehidupan masyarakat Asia (Indonesia) yang masih menekankan pada kepentingan karier dibanding dengan kepentingan keluarga. Ini berbeda dengan masyarakat USA yang mementingkan keluarga dibanding karier (Yang et al. , 2000).

Hasil analisis korelasi menunjukkan bahwa Spousal Support berkorelasi positif dengan skala lain, menunjukkan bahwa responden lebih menyukai pasangan hidup yang mempunyai kesadaran untuk mencoba membuat keluarga dan karier lebih menyenangkan. Selain itu, Dominance juga berkorelasi positif dengan skala lain, menunjukkan bahwa responden lebih menyukai pasangan hidup yang lebih berkarier untuk keluarga, bukan kedua-duanya.

Ada beberapa perbedaan dalam interkorelasi skor skala antara pria dan wanita Hasil interkorelasi skor skala antara pria dan wanita dapat dilihat pada Tabel 4. 
Tabel 4.Statistik Deskriptif dan Interkorelasi Score Skala dengan Jenis Kelamin

\begin{tabular}{|c|c|c|c|c|c|c|c|c|c|c|}
\hline No. & Skala & Mean & $\begin{array}{l}\text { Standar } \\
\text { Deviasi }\end{array}$ & 1 & $1 a$ & $1 b$ & 2 & 3 & 4 & 5 \\
\hline & Wanita, $N=93$ & & & & & & & & & \\
\hline 1 & Fam Foc & 73,99 & 8,97 & & & & & & & \\
\hline $1 a$ & I Def & 44,12 & 6,22 & $0,882^{* *}$ & & & & & & \\
\hline $1 b$ & One Def & 29,87 & 4,56 & $0,766^{* *}$ & $0,372^{\star *}$ & & & & & \\
\hline 2 & Balance & 55,90 & 5,04 & 0,200 & 0,181 & 0,146 & & & & \\
\hline 3 & Car Foc & 24,12 & 5,25 & 0,123 & 0,147 & 0,042 & 0,159 & & & \\
\hline 4 & Domin & 32,62 & 4,51 & $0,372^{* *}$ & $0,355^{* *}$ & $0,248^{*}$ & $0,314^{* *}$ & 0,081 & & \\
\hline 5 & Spo Sup & 36,02 & 5,81 & $0,483^{* *}$ & $0,372^{\star *}$ & $0,442^{\star *}$ & $0,331^{\star *}$ & 0,149 & $0,516^{\star *}$ & \\
\hline \multirow[t]{2}{*}{6} & Indep & 14,06 & 5,24 & $-0,073$ & $-0,120$ & 0,019 & 0,028 & 0,146 & $-0,005$ & $-0,022$ \\
\hline & Pria, $N=124$ & & & & & & & & & \\
\hline 1 & Fam Foc & 68,22 & 8,49 & & & & & & & \\
\hline $1 \mathrm{a}$ & I Def & 38,22 & 5,98 & $0,891^{* *}$ & & & & & & \\
\hline $1 b$ & One Def & 30,00 & 4,17 & $0,758^{\star *}$ & $0,380 * *$ & & & & & \\
\hline 2 & Balance & 53,85 & 6,64 & $0,292^{* *}$ & $0,342^{\star *}$ & 0,103 & & & & \\
\hline 3 & Car Foc & 24,60 & 5,02 & $0,203^{*}$ & $0,196^{\star}$ & 0,131 & 0,231 ** & & & \\
\hline 4 & Domin & 37,81 & 5,69 & $0,439 * *$ & $0,445^{* *}$ & $0,257^{* *}$ & $0,419 * *$ & $0,196^{*}$ & & \\
\hline 5 & Spo Sup & 36,78 & 5,82 & $0,269 * *$ & $0,190 *$ & $0,276^{\star *}$ & $0,397^{\star *}$ & $0,310 * *$ & $0,418^{\star *}$ & \\
\hline 6 & Indep & 15,39 & 4,52 & $0,208^{*}$ & $0,209^{*}$ & 0,124 & 0,028 & 0,080 & $-0,054$ & 0,035 \\
\hline
\end{tabular}

1. Family Focus; 1a. I Defer; 1b. Someone defers; 2. Balance; 3. Career Focus; 4. Dominance; 5. Spousal Support; 6 . Independence

${ }^{*} p<=0.01$

${ }^{* *} p<=0.05$

Hasil interkorelasi skor skala antara pria dan wanita menunjukkan bahwa ada hubungan atau korelasi positif yang signifikan antara family focus dan career focus pada pria namun tidak signifikan pada wanita. Ini menunjukkan bahwa seorang suami dapat menfokuskan baik keluarga maupun karier atau kedua-duanya. Korelasi signifikan untuk pria memperlihatkan hubungan positif pada pria antara subskala I defer dan skala career focus.

Pola hubungan antara skala satu dengan semua skala yang lain pada pria dan wanita tidak menunjukkan adanya perbedaan. Wanita mempunyai score rendah pada subskala someone defers, career focus, dan independence. Sedang skala yang scorenya tinggi adalah balance, I defer, spousal support, dan dominance. Pada pria, pola hubungannya sama dengan wanita karena scorenya yang rendah pada subskala someone defers, career focus, dan independence sedangkan score yang tinggi pada skala I defer, balance, dominance, dan spousal support. Pada pria, korelasinya lebih tinggi dan hubungan I defer dengan career focus dan independence semua signifikan, sebaliknya pada wanita korelasinya lebih rendah dan hubungan I defer dengan career focus dan independence tidak semua signifikan.

Pada pria, ada korelasi positif antara balance dan career focus, sebaliknya tidak signifikan pada wanita, mengindikasikan bahwa jika saya berkonsentrasi pada karier saya, saya dapat mengalihkan sesuatu yang berhubungan dengan rumah dan berpartisipasi dalam membuat keputusan harian (pria) dan jika saya tunduk/patuh untuk memperhatikan keluarga saya maka saya memerlukan pasangan hidup yang mau berhubungan dengan rumah dan supportive terhadap karier saya (wanita).

Pada wanita, independence tidak berkorelasi dengan beberapa skala lainnya sedang pada pria, independence berkorelasi positif dengan family focus dan subskala I defer, dan tidak berkorelasi dengan beberapa skala yang lain. Pada pria dan wanita, tidak ada korelasi antara independence dan spousal support (jika saya ingin liburan atau sosialisasi tanpa istri, saya tidak perlu supportive istri). Pada pria dan wanita, ada korelasi positif antara balance dan spousal support (jika istri saya supportive maka saya ingin berbagi tugas pekerjaan rumah tangga). 
Hasil penelitian ini tidak konsisten dengan hasil penelitian Sander et al. (1998). Sander et al. (1998) menemukan bahwa ada hubungan negatif signifikan antara family focus dan career focus pada wanita dan sebaliknya tidak pada pria; ada hubungan positif signifikan antara career focus dan balance pada wanita dan sebaliknya tidak pada pria; ada hubungan negatif antara family focus dan independence pada wanita dan sebaliknya tidak pada pria; ada hubungan positif signifikan antara independence dan spousal support pada pria dan sebaliknya tidak pada wanita; dan ada hubungan negatif antara balance dan spousal support pada pria dan sebaliknya tidak pada wanita. Perbandingan hasil interkorelasi skor skala dengan jenis kelamin antara penelitian sebelumnya ( Sander et al., 1998) dengan penelitian ini dapat dilihat pada Tabel 5.

Tabel 5. Hasil interkorelasi skor skala dengan jenis kelamin

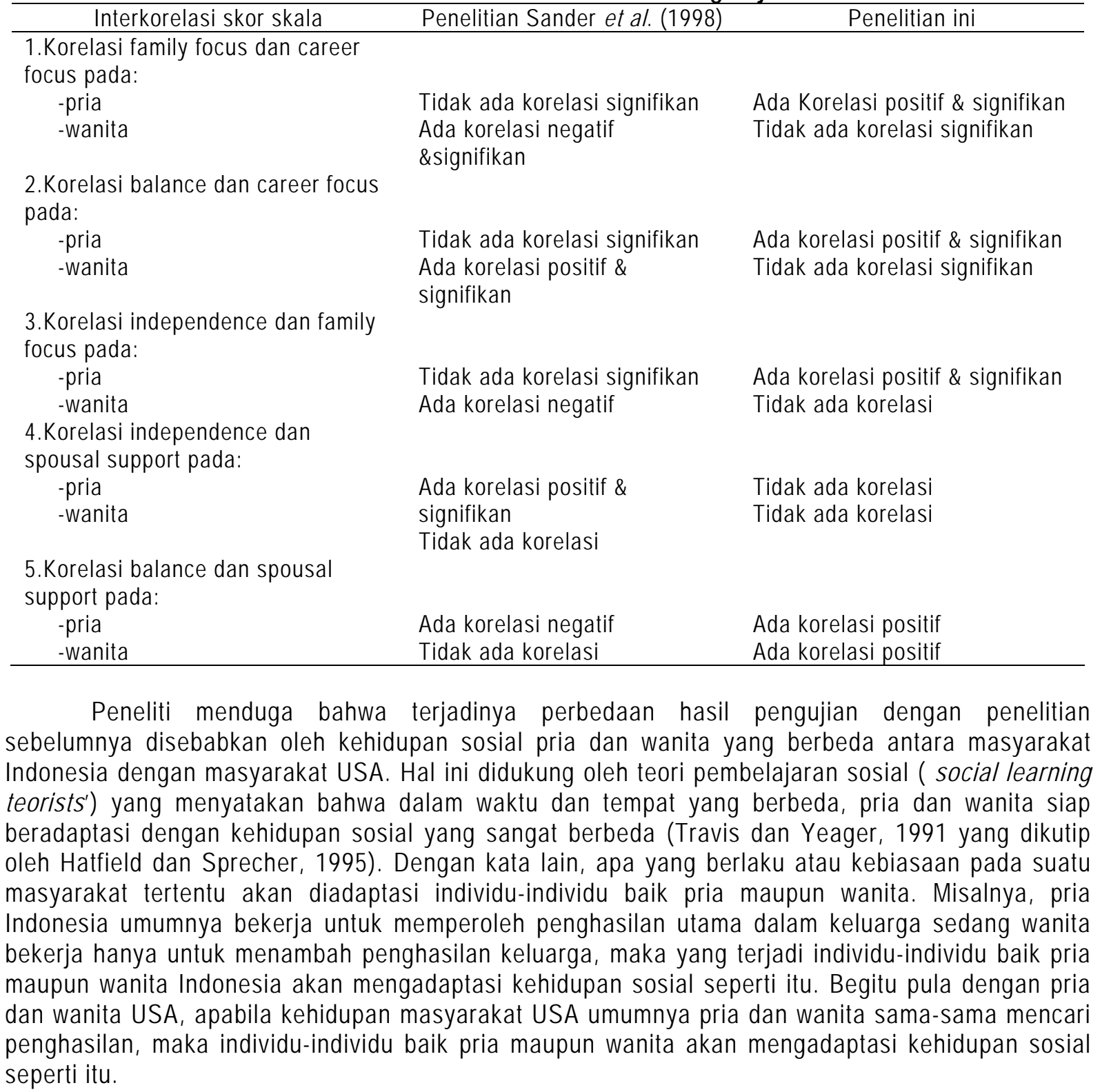




\subsection{Hasil uji Hipotesis}

Hasil uji hipotesis 1 ditemukan bahwa Spousal Support berkorelasi positif dengan skala lain. Ini menunjukkan bahwa responden lebih menyukai pasangan hidup yang mempunyai kesadaran untuk mencoba membuat keluarga dan karier lebih menyenangkan. Selain itu, Dominance juga berkorelasi positif dengan skala lain, menunjukkan bahwa responden lebih menyukai pasangan hidup yang lebih berkarier untuk keluarga, bukan kedua-duanya.

Hasil uji sub-sub hipotesis ( $\mathrm{H} 1 \mathrm{a}-\mathrm{H} 1 \mathrm{~g})$ ditemukan bahwa ada hubungan yang signifikan antara spousal support dan balance pada pria(H1a). Melalui analisa korelasi diperoleh angka korelasi $0,397^{* *}$ dengan probabilitas 0,000 menunjukkan kesimpulan bahwa ada hubungan yang signifikan antara spousal support dan balance. Pada wanita juga ditemukan ada hubungan yang signifikan antara spousal support dan balance(H1a). Melalui analisa korelasi diperoleh angka korelasi 0,331** dengan probabilitas 0,001 menunjukkan kesimpulan bahwa ada hubungan yang signifikan antara spousal support dan balance pada wanita.

Peneliti menemukan bahwa ada hubungan yang signifikan antara family focus dan career focus pada pria(H1b). Melalui analisa korelasi diperoleh angka korelasi $0,203^{*}$ dengan probabilitas 0,024 menunjukkan kesimpulan bahwa ada hubungan yang signifikan antara family focus dan career focus pada pria. Sebaliknya pada wanita ditemukan bahwa tidak ada hubungan yang signifikan antara family focus dan career focus(H1b). Melalui analisa korelasi diperoleh angka korelasi 0,123 dengan probabilitas 0,240 menunjukkan kesimpulan bahwa tidak ada hubungan yang signifikan antara family focus dan career focus pada wanita.

Peneliti menemukan bahwa ada hubungan yang signifikan antara career focus dan balance pada pria(H1c). Melalui analisa korelasi diperoleh angka korelasi $0,231^{* *}$ dengan probabilitas 0,010 menunjukkan kesimpulan bahwa ada hubungan yang signifikan antara career focus dan balance pada pria. Sebaliknya pada wanita, peneliti tidak menemukan hubungan yang signifikan antara career focus dan balance(H1c). Melalui analisa korelasi diperoleh angka korelasi 0,159 dengan probabilitas 0,128 menunjukkan kesimpulan bahwa tidak ada hubungan yang signifikan antara career focus dan balance pada wanita.

Pada pria ditemukan bahwa ada hubungan yang signifikan antara independence dan family focus(H1d). Melalui analisa korelasi diperoleh angka korelasi $0,208^{*}$ dengan probabilitas 0,021 menunjukkan kesimpulan bahwa ada hubungan yang signifikan antara independence dan family focus pada pria. Sebaliknya pada wanita ditemukan bahwa tidak ada hubungan yang signifikan antara independence dan family focus(H1d). Melalui analisa korelasi diperoleh angka korelasi $-0,073$ dengan probabilitas 0,485 menunjukkan kesimpulan bahwa tidak ada hubungan yang signifikan antara independence dân family focus pada wanita.

Pada pria ditemukan bahwa tidak ada hubungan yang signifikan antara independence dan career focus(H1e). Melalui analisa korelasi antara independence dan career focus diperoleh angka korelasi 0,080 dengan probabilitas 0,379 menunjukkan kesimpulan bahwa tidak ada hubungan yang signifikan antara independence dan career focus pada pria. Pada wanita juga ditemukan bahwa tidak ada hubungan yang signifikan antara independence dan career focus(H1e). Melalui analisa korelasi antara independence dan career focus diperoleh angka korelasi 0,146 dengan probabilitas 0,163 menunjukkan kesimpulan bahwa tidak ada hubungan yang signifikan antara independence dan career focus pada wanita.

Pada pria ditemukan bahwa tidak ada hubungan yang signifikan antara independence dan dominance(H1f). Melalui analisis korelasi diperoleh angka korelasi -0,054 dengan probabilitas 0,549, menunjukkan kesimpulan bahwa tidak ada hubungan yang signifikan antara independence dan dominance pada pria. Pada wanita juga ditemukan bahwa tidak ada hubungan yang signifikan antara independence dan dominance(H1f). Melalui analisa korelasi diperoleh angka korelasi -0,005 dengan probabilitas 0,962 , menunjukkan kesimpulan bahwa tidak ada hubungan yang signifikan antara independence dan dominance pada wanita. 
Pada pria ditemukan bahwa tidak ada hubungan yang signifikan antara independence dan spousal support(H1g). Melalui analisa korelasi diperoleh angka korelasi 0,035 dengan probabilitas 0,701 menunjukkan kesimpulan bahwa tidak ada hubungan yang signifikan antara independence dan spousal support pada pria. Pada wanita juga ditemukan bahwa tidak ada hubungan yang signifikan antara independence dan spousal support $(\mathrm{H} 1 \mathrm{~g})$. Melalui analisa korelasi diperoleh angka korelasi 0,022 dengan probabilitas 0,833 menunjukkan kesimpulan bahwa tidak ada hubungan yang signifikan antara independence dan spousal support pada wanita.

\section{SIMPULAN, IMPLIKASI, KETERBATASAN DAN SARAN}

\subsection{Simpulan}

Spousal support dan dominance, mempunyai hubungan yang signifikan dan positif dengan skala lain. Ini menunjukkan bahwa responden lebih menyukai pasangan hidup yang mempunyai kesadaran untuk mencoba membuat keluarga dan karier lebih menyenangkan.

Ada hubungan yang signifikan dan positif antara spousal support dan balance pada pria dan wanita. Ini menunjukkan bahwa antara suami dan istri saling mendukung dan berbagi tugas rumah tangga.

Ada hubungan yang signifikan dan positif antara family focus dan career focus pada pria dan sebaliknya tidak signifikan pada wanita. Ini menunjukkan bahwa seorang suami dapat membuktikan hanya menfokuskan pada keluarga dan karier atau kedua-duanya.

Ada hubungan yang signifikan dan positif antara career focus dan balance pada pria dan sebaliknya tidak signifikan pada wanita. Ini menunjukkan bahwa jika seorang suami berkonsentrasi pada karier maka suami tersebut dapat mengalihkan sesuatu yang berhubungan dengan kehidupan rumah tangga dan berpartisipasi dalam membuat keputusan harian dan jika seorang istri berkonsentrasi pada keluarga maka istri tersebut memerlukan suami yang mau berhubungan dengan kehidupan rumah tangga dan berpartisipasi dalam membuat keputusan.

Ada hubungan yang signifikan dan positif antara independence dan family focus pada pria dan sebaliknya tidak signifikan pada wanita. Ini menunjukkan bahwa seorang suami mau memperhatikan kehidupan rumah tangganya, bebas sosialisasi, dan melakukan liburan sendiri dan sebaliknya seorang istri yang menfokuskan pada rumah tangganya tidak dapat bersosialiasasi dan melakukan liburan sendiri.

Tidak ditemukan hubungan yang signifikan antara independence dan career focus pada pria dan wanita. Ini menunjukkan bahwa suami/istri yang tidak menfokuskan pada karier maka bebas bersosialisasi dan sebaliknya jika suami/istri menfokuskan pada karier maka tidak bebas bersosialisasi.

Tidak ditemukan hubungan yang signifikan antara independence dan dominance pada pria dan wanita. Ini menunjukkan bahwa suami/istri yang tidak dominan dalam rumah tangga mereka maka bebas bersosialisasi dan sebaliknya jika suami/istri dominan maka tidak bebas bersosialisasi.

Tidak ditemukan hubungan yang signifikan antara independence dan spousal support pada pria dan wanita. Ini menunjukkan bahwa seorang suami yang ingin melakukan liburan atau sosialisasi tanpa istrinya maka tidak perlu supportif istri.

\subsection{Implikasi}

Penelitian ini dapat dimanfaatkan dan dikembangkan oleh para praktisi manajemen sumber daya manusia (MSDM) untuk mengambil kebijakan meningkatkan kinerja SDM melalui meningkatnya kepuasan pekerjaan karena pengaruh kepuasan keluarga. Mengingat kepuasan keluarga mempengaruhi tingkat kepuasan pekerjaan dan akhirnya dapat meningkatkan kinerja, maka para praktisi SDM dapat meningkatkan kepuasan keluarga dengan membuat kebijakan membantu para pekerja untuk menciptakan keseimbangan antara kehidupan dalam keluarga dan kehidupan kerja. Dengan adanya keseimbangan antara kehidupan keluarga dan kerja maka produktivitas pekerja akan 
meningkat dan ini akan menguntungkan perusahaan. Sebagai imbalannya perusahaan dapat menawarkan program-program berupa bantuan perawatan untuk keluarga pekerja dan asuransi kesehatan (Mercer,1991 dikutip oleh Yasin, 1999).

\subsection{Keterbatasan penelitian dan saran bagi penelitian mendatang}

Penelitian ini masih tergolong baru atau single study sehingga tidak dapat membuat reliabilitas dan validitas dari sebuah instrumen baru, karena itu penelitian ini harus dipandang sebagai permulaan dari proses konstruk validitas. Penelitian mendatang perlu menilai perubahan diskriminan dan validitas yang dihubungkan dengan kriteria CFAM, penilaian ini diperlukan untuk menentukan apakah instrumen CFAM sesuai alat ukurnya.

Penelitian ini hanya menggunakan subyek penelitian yang terbatas. Peneliti menggunakan mahasiswa tingkat akhir di dua Perguruan tinggi yaitu Universitas Gadjah Mada dan Universitas Atma Jaya Yogyakarta. Karena penelitian ini menggunakan subyek yang sangat terbatas maka penelitian mendatang dapat mengembangkan penelitian dengan sampel yang lebih luas dengan populasi yang berbeda sehingga hasilnya dapat digeneralisasikan dengan baik.

Penelitian ini hanya menguji hubungan antara berbagai dimensi sikap individual baik pria maupun wanita dalam mengelola keluarga dan karier. Hasil penelitian ini tidak menunjukkan apakah pria dan wanita cenderung mementingkan keluarga atau karier. Untuk penelitian mendatang, peneliti dapat meneliti perbedaan sikap individu terhadap pengelolaan interface karier dan keluarga antara pria dan wanita.

\section{DAFTAR PUSTAKA}

Cooper, Donald R., \& Emory, C. William (1995), Business research methods, Irwin, fifth edition.

Edwards, J.R., \& Harrisson, V.R. (1992), "Job demands and worker health: Three-dimensional reexaminiation of the relationship between person-environment fit and strain", Journal of Applied Psychology, 78: 628-648.

Frone, M.R., Russel, M., \& Cooper, M.L. (1994), "Relationship between job and family satisfaction: Causal or noncausal covariation?" Journal of Management, 20: 565-579.

Hatfield, E., \& Sprecher, S. (1995), “Men's and women's preferences in marital patners in The United States, Rusia, and Japan", Journal of cross-cultural psychology, Vol. 26 (6): 728-750.

Higgins, C.A., \& Duxbury, L.E. (1992), "Work -family conflict: A comparison of dual-career and traditional-career men", Journal of Organizational Behavior, Vol. 13: 389-411.

Junaedi, Sheellyana, M., F. 2000. Pengaruh ketidakpuasan konsumen, karakteristik, kategori produk, dan kebutuhan mencari variasi terhadap keputusan perpindahan merk. Thesis S2 Universitas Gadjah Mada (tidak diterbitkan), Yogyakarta, 41-42.

Kim, J., \& Mueller, C.W. (1978), Introduction to factor analysis. Sage Publication, Inc.

Martin, P.Y., Harrison, D., \& Dinitto, D. (1983), "Advancement for women in hierarchical organizations: A multilevel analysis of problems and prospects", The Journal of Applied Behavioral Science, Vol. 19: 19-33. 
Sander, M.M., Lengnick-Hall, C.A., Lengnick-Hall, M.L., \& Steele-Clapp, L. (1998), "Love and work: career-family attitudes of new entrants into the labor force", Journal of Organizational Behavior, 19: 603-619.

Sekaran, U. (1992), Research Methods For Business. John Wiley \& Sons, Inc, second edition.

Sharma, S. (1996), Applied Multivariate Techniques. John Wiley \& Sons, Inc.

Singh, S. (1994), "Gender differences in work values and personality characteristics among Indian executives", Journal of Social Psychology, 134 (5): 699-700.

SPSS Base 8.0. (1998), Applications Guide. SPSS Inc.

Vinokur, A.D., Pierce, P.F., \& Buck, C.L. (1999), "Work-family conflicts of women in the Air Force: their influence on mental health and functioning", Journal of Organizational Behavior, 20: 865-878.

Williams, K.L., \& Alliger, G.M. (1994), "Role stressor, mood spillover, and perceptions of work-family conflict in employed parents", Academy of Management Journal, 37: 837-868.

Wallace, J.E. (1999), "Work-to-nonwork conflict among married male and female lawyers", Journal of Organizational Behavior, 20: 797-816.

Yasin, A. (1999), Studi tentang pengaruh timbal balik antara kepuasan pekerjaan dan kepuasan keluarga. Thesis S2 Universitas Gadjah Mada (tidak diterbitkan), Yogyakarta, 48-49.

Yang, N., Chen, C.C., Choi, J., \& Zou, Y. (2000), "Sources of work-family conflict: A SINO-U.S. comparison of the effects of work and family demands", Academy of Management Journal, Vol. 43(1):113-123. 